http://dx.doi.org/10.1590/1678-4162-8949

Arq. Bras. Med. Vet. Zootec., v.68, n.5, p.1267-1274, 2016

\title{
Histopathological findings in lungs of hawksbill turtles collected on the coasts of the states of Espírito Santo and Rio de Janeiro, Brazil
}

\author{
[Achados histopatológicos em pulmões de tartarugas-de-pente procedentes dos litorais dos \\ estados do Espírito Santo e do Rio de Janeiro, Brasil] \\ M.A. Silva ${ }^{1}$, H.L. Jerdy ${ }^{2}$, R.B. Ribeiro ${ }^{2}$, R.M. Medina ${ }^{2}$, M.B.R.G. Petronilha ${ }^{2}$, \\ E.Shimoda ${ }^{3}$, M.R. Werneck ${ }^{4}$, J.G. Andrade ${ }^{1}$, E.C.Q. Carvalho ${ }^{2}$ \\ ${ }^{1}$ Universidade Federal do Espírito Santo - Alegre, ES \\ ${ }^{2}$ Universidade Estadual do Norte Fluminense Darcy Ribeiro - Campos dos Goytacazes, RJ \\ ${ }^{3}$ Universidade Cândido Mendes - Campos dos Goytacazes, RJ \\ ${ }^{4}$ Autônomo - Ubatuba, SP
}

\begin{abstract}
The present work aimed to report the histopathological findings verified in lungs of hawksbill turtles (Eretmochelys imbricata) retrieved from the coasts of the states of Espírito Santo and Rio de Janeiro, Brazil. Between the years 2010 and 2014, 29 E. imbricata individuals were found stranded on the coasts, already dead or dying during treatment. Lung samples of all specimens were collected during necropsies, fixed in $10 \%$ neutral buffered formalin, subjected to routine histological processing and classified histomorphologically. The findings revealed that $37.93 \%$ of the specimens presented lung lesions. Of these, $90.91 \%$ were rescued alive and $9.09 \%$ were found dead; $63.63 \%$ were females and $36.37 \%$ were males. The mean weight was $5.44 \mathrm{Kg}$ and the mean length $39 \mathrm{~cm}$, characterizing young individuals. The animals originated from São Francisco de Itabapoana - RJ, Aracruz - ES, São Mateus - ES, Guarapari ES, Linhares - ES, Itapemirim - ES, and Anchieta - ES. Macroscopic analysis revealed presence of foam, hyperemia, nodules in the parenchyma, cyst and caseous material. Microscopic examination evidenced heterophilic bronchopneumonia, parasitic granulomatous pneumonia caused by spirorchiids, bacterial granulomatous pneumonia, fungal granulomatous pneumonia, and congestion. It was concluded that juvenile specimens of Eretmochelys imbricata, females and males, originated from the states of Espírito Santo and Rio de Janeiro and found stranded both alive or dead, have significant lung lesions, mainly inflammatory ones, associated or not with infectious agents.
\end{abstract}

Keywords: pneumonia, Eretmochelys imbricata, granulomas.

\section{RESUMO}

Objetivou-se com este trabalho relatar os achados histopatológicos em pulmões de Eretmochelys imbricata provenientes dos litorais dos estados do Espírito Santo e do Rio de Janeiro, Brasil. Amostras de pulmões de 29 E. imbricata foram coletadas, durante os anos de 2010 a 2014, em necropsias de espécimes encalhadas mortas ou que vieram a óbito durante o tratamento, nos litorais dos estados do Espírito Santo e do Rio de Janeiro, fixadas em formalina tamponada neutra a $10 \%$, submetidas ao processamento histológico de rotina e classificadas histomorfologicamente. Os dados dos animais mostraram que 37,93\% dos animais apresentaram lesões pulmonares. Destes, 90,91\% foram encontrados vivos e 9,09\% morto, 63,63\% eram fêmeas e 36,37\% machos. O peso médio foi de 5,44kg, e o comprimento médio de $39 \mathrm{~cm}$, o que caracterizou animais juvenis. Os animais eram provenientes de São Francisco de Itabapoana - RJ, Aracruz - ES, São Mateus - ES, Guarapari - ES, Linhares - ES, Itapemirim - ES e Anchieta - - ES. Á macroscopia, observou-se: presença de espuma, hiperemia, nódulos no parênquima, cisto e cáseo. Ao exame microscópico, foram encontrados broncopneumonia heterofílica, pneumonia granulomatosa parasitária, causadas por espirorquídeos, pneumonia granulomatosa bacteriana, pneumonia granulomatosa fúngica e congestão. Conclui-se que exemplares

Recebido em 22 de fevereiro de 2016

Aceito em 18 de abril de 2016

E-mail: mvmariaaparecida@gmail.com 
juvenis de Eretmochelys imbricata, fêmeas e machos, provenientes dos estados do Espírito Santo e do Rio de Janeiro e encalhados tanto vivos quanto mortos, apresentam lesões pulmonares importantes, principalmente as de origem inflamatória, associadas ou não a agentes infecciosos.

Palavras-chave: pneumonia, Eretmochelys imbricata, granulomas

\section{INTRODUCTION}

Five turtle species inhabit the Brazilian coast: Chelonia mydas, Caretta caretta, Eretmochelys imbricata, Lepidochelys olivacea and Dermochelys coriacea. E. imbricata Linnaeu 1766 , commonly known as hawksbill turtle, is critically endangered at national and international level (Marcovaldi and Marcovaldi, 1999).

In the national territory, young animals are distributed all over the north-northeastern coast, and in smaller scale in the south-southeast (Marcovaldi et al., 2011). As feeding areas, they use the beaches of the states of São Paulo (SP), in the northern coast, and Ceará (CE) (Gallo et al., 2006), and mainly the oceanic islands of Fernando de Noronha - Pernambuco (PE), Atol das Rocas - Rio Grande do Norte (RN), Abrolhos - Bahia (BA), Arvoredo - Santa Catarina (SC) and the island of Trindade Espírito Santo (ES) (Marcovaldi et al., 2011).

Free-living turtles may present lung alterations caused by viral, fungal, bacterial and parasitic infections, besides neoplasia and obstructions (Flint et al., 2009). However, the histological descriptions of lesions in hawksbill turtles, though existing, are scarce and describe only those caused by parasites' eggs. In Australia, Glazebrook et al. (1989) and Glazebrook and Campbell (1990) reported microscopic lesions caused by Spirorchiidae eggs in four and two hawksbill turtles, respectively. Dutra et al. (2012), on the Brazilian coast, and Santoro et al. (2015) in Costa Rica analyzed only one animal.

Therefore, the aim of the present work was to report the histopathological findings in lungs of hawksbill turtles originated from the coasts of Espírito Santo and Rio de Janeiro, Brazil.

\section{MATERIAL AND METHODS}

Samples from 29 lungs of E. imbricata were collected between the years 2010 and 2014 during necropsies of specimens found stranded, already dead or dying during treatment, on the coasts of Espírito Santo (ES) and Rio de Janeiro (RJ), Brazil. Analyses of the lungs were authorized by federal licenses for activities with scientific purposes (SISBIO) 12431-4.

The samples were fixed in $10 \%$ neutral buffered formalin and dispatched, along with a detailed record card containing the data about the animals, to the Laboratory of Pathological Anatomy at the Veterinary Hospital of the State University of Norte Fluminense Darcy Ribeiro (UENF). The samples were processed according to routine histopathological techniques, being stained with hematoxylin-eosin (HE), Grocott's methenamine silver nitrate (GMS) upon suspicion of fungal infection, or Ziehl-Neelsen stain in case of bacterial infection, and analyzed by light microscopy.

The descriptive statistical analysis was used for the variables gender, size, and weight of the animals, conditions and description of the locations where the animals were found, and macro- and microscopic classification of the lung lesions. Pearson's coefficients of correlation between the macro- and microscopic characteristics of the lesions were also obtained. The statistical analyses were carried out using the application "systems for statistic and genetic analyses" (MINITAB ${ }^{\circledR}$, version 15.1.1.0), adopting 5\% significance level.

\section{RESULTS}

Histopathology of the lungs revealed that $37.93 \%(11 / 29)$ of the animals had lung lesions. Of these, ten $(90.91 \%)$ were found alive, having died during treatment, and one $(9.09 \%)$ was found dead.

Of the animals presenting lung lesions, seven (63.63\%) were females and four $(36.37 \%)$ were males. The animals presented mean weight of $5.44 \mathrm{~kg}$ (range: $2.05-28 \mathrm{~kg}$ ) and mean length of $39 \mathrm{~cm}$ (range: $31-76.5 \mathrm{~cm}$ ). The afflicted animals originated from the cities of São Francisco de Itabapoana - RJ: 27.28\% (3/11); Aracruz - ES: 
18.18\% (2/11); São Mateus - ES: 18.18\% (2/11); Guarapari - ES: $9.09 \%$ (1/11); Linhares - ES: 9.09\% (1/11); Itapemirim - ES: 9.09\% (1/11); and Anchieta - ES: 9.09\% (1/11).

The lung alterations found in the macroscopic analysis were presence of foam in $54.54 \%$ $(6 / 11)$, hyperemia in $27.27 \%(3 / 11)$, nodules in the parenchyma in $18.18 \%(2 / 11)$, cysts in $9.09 \%$ $(1 / 11)$, and caseous material in $9.09 \%(1 / 11)$. These results demonstrate that more than one macroscopic lesion can be found in the lungs of a single animal. All (100\%) of the animals presented bad physical shape. Fig. 1 illustrates macroscopic lesion observed in the respiratory system of E. imbricata.

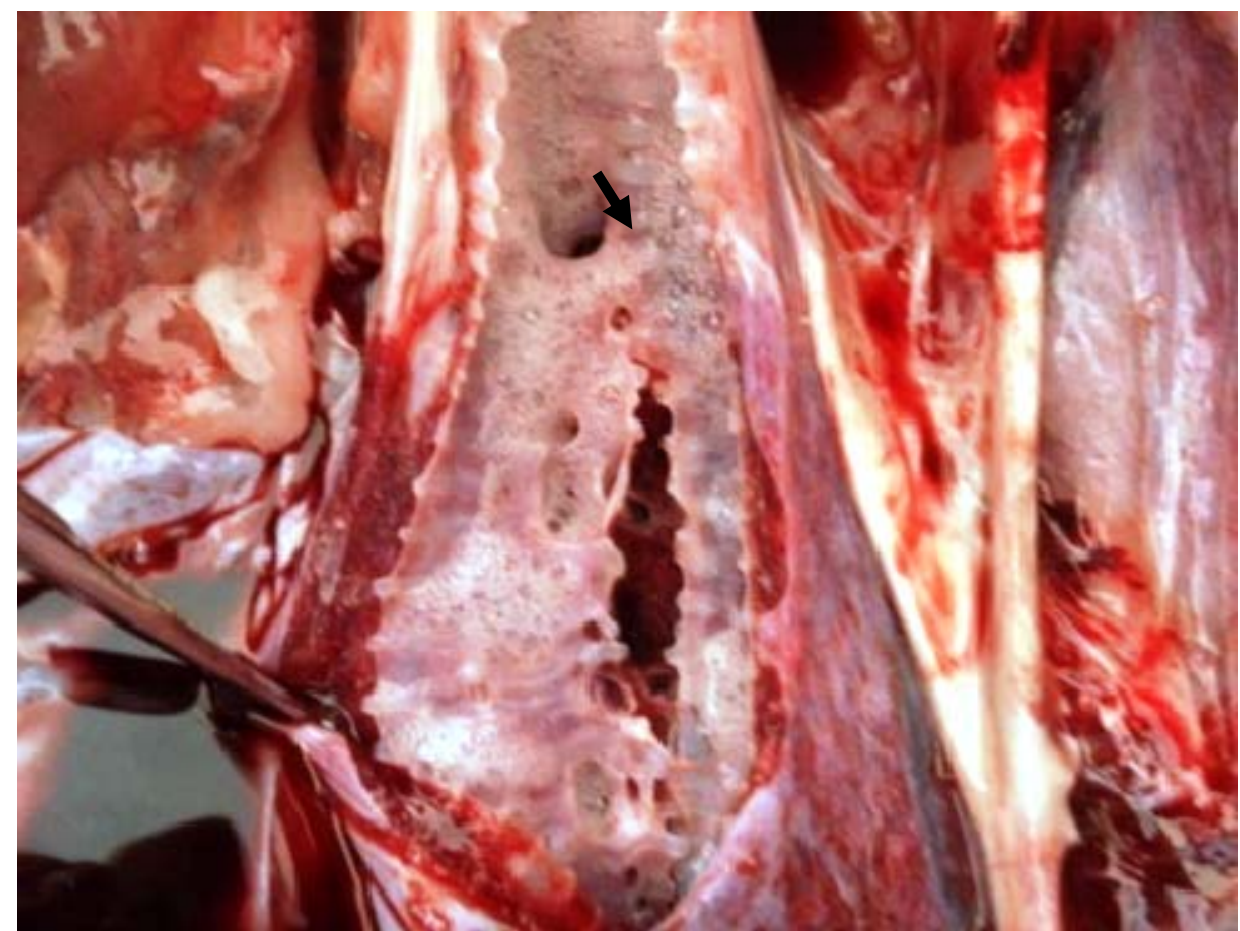

Figure 1. Photomacrography of lung lesion in Eretmochelys imbricata found stranded on the coasts of Espírito Santo and Rio de Janeiro, Brazil. Presence of foam (arrow) in a lung. Campos dos Goytacazes RJ, 2015.

The lesions found during microscopic examination were heterophilic bronchopneumonia in $45.45 \%$ of the animals (5/11), parasitic granulomatous pneumonia caused by spirorchiids in $27.28 \%$ (3/11), bacterial granulomatous pneumonia in $27.28 \%(3 / 11)$, fungal granulomatous pneumonia in $9.09 \%(1 / 11)$, and congestion in $9.09 \%(1 / 11)$ of the individuals. One animal presented bacterial granulomatous pneumonia and heterophilic bronchopneumonia, and another presented parasitic granulomatous pneumonia and bacterial granulomatous pneumonia. The animal found dead presented heterophilic bronchopneumonia. Fig. 2 illustrates the lung lesions observed in this study.
Positive correlation was also found between granulomatous pneumonia due to parasites' eggs (family Spirorchiidae) and lung with nodules $(\mathrm{r}=$ 0.354, $\mathrm{p}=0.0296$ ), indicating that, upon identifying nodules in the lungs, it is possible that granulomatous inflammatory reaction caused by parasites' eggs be found during microscopic examination.

Positive correlation also existed between bacterial pneumonia and cyst in the lung ( $\mathrm{r}=$ 0.556, $\mathrm{p}=0.0009)$ and lung with caseous material $(\mathrm{r}=0.556, \mathrm{p}=0.0009)$, which implies that when bacterial pneumonia is detected, it is likely that the lung will present cyst and/or caseous material. 


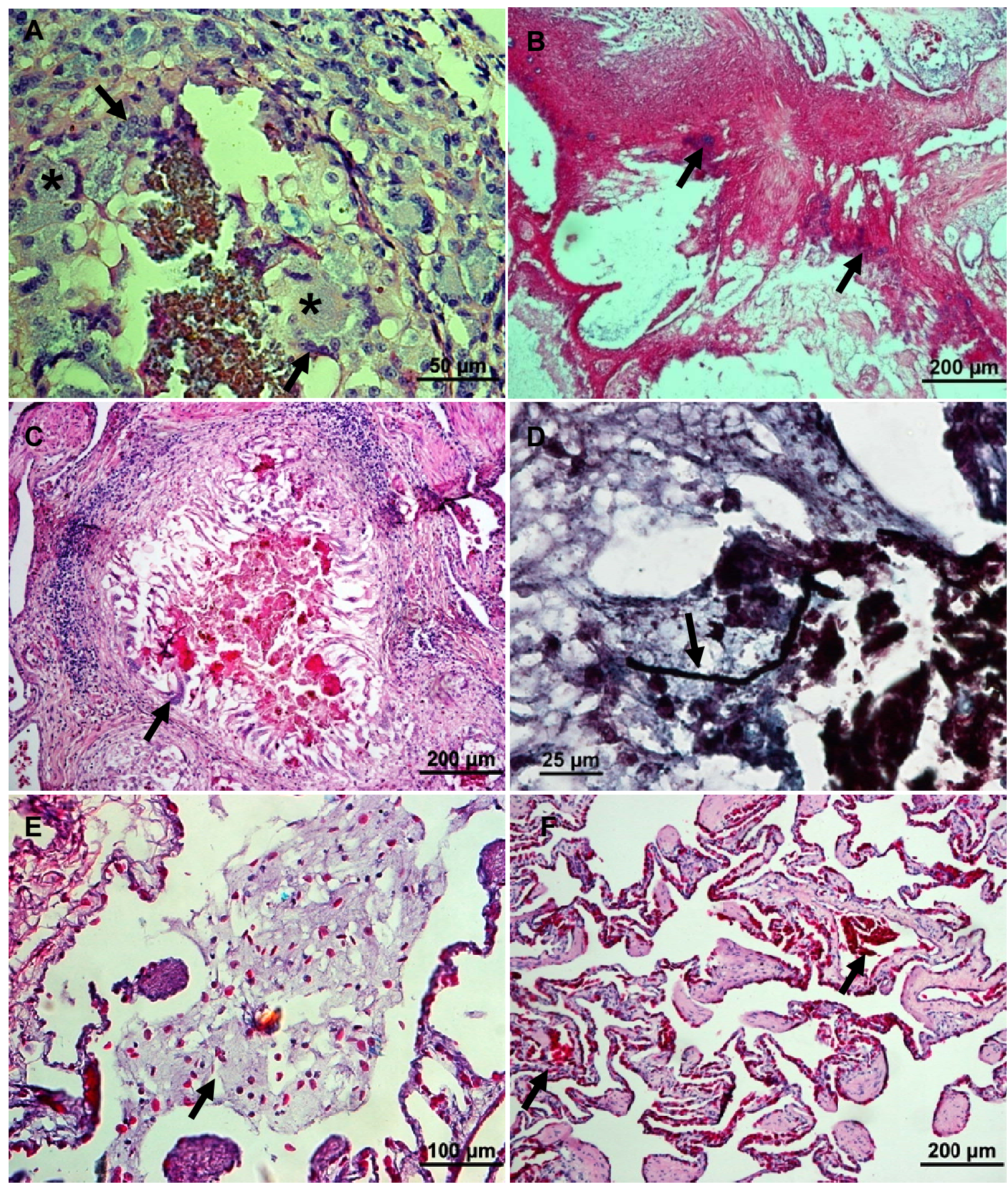

Figure 2. Photomicrography of lesions in lungs of Eretmochelys imbricata stranded on the coasts of Espírito Santo and Rio de Janeiro, Brazil. A - Bacterial granulomatous pneumonia, bacterial colony (*), giant cell (arrow). B - Bacterial granulomatous pneumonia, bacterial colony (arrow) inside the granuloma. C - Mycotic granulomatous pneumonia, giant cell (arrow). D - Mycotic granulomatous pneumonia, fungal hyphae (arrow). E - Heterophilic bronchopneumonia, fibrinous material inside the bronchioles (arrow). F - Lung congestion, congested vessels (arrow). A, B, C, E and F: hematoxylineosin staining; D: Grocott's staining. Campos dos Goytacazes - RJ, 2015. 


\section{DISCUSSION}

The percentage of animals in this study presenting lung alterations was considerable. According to Flint et al. (2009), such alterations frequently occur in turtles. Although the majority of the animals were found alive, these individuals were weakened, underwent treatment, but did not resist and died. There are two possible explanations for this: First, lung afflictions had weakened the animals, so that they were stranded alive and, despite treatment, did not manage to fight the infections; or second, the animals were stranded alive for some unknown reason and, upon being subjected to treatment, became weak and susceptible to lung infections. In the animal found dead, heterophilic bronchopneumonia was probably the main lesion leading to death.

In Brazil, E. imbricata with curved carapace length (CCL) smaller than $80 \mathrm{~cm}$ and weight lower than $40 \mathrm{~kg}$ are considered young (Marcovaldi and Marcovaldi, 1985); therefore, all animals in this study were young individuals. Considering that this is a critically endangered species, the death of young specimens is an aggravating aspect, as the number of adult individuals is thus potentially decreased.

The animals presenting lung alterations were retrieved in the states of Espírito Santo and Rio de Janeiro. Young E. imbricata individuals are distributed in small scale along the coasts of the South-Southeast (Marcovaldi et al., 2011). In the Southeast region, the animals use beaches in the state of São Paulo (Gallo et al., 2006) and the oceanic island of Trindade - ES for feeding (Marcovaldi et al., 2011). Although there are no reports on the occurrence of young hawksbill turtle specimens in Rio de Janeiro, this state is possibly part of the species' migration route and, because the animals were debilitated, they stranded on beaches of its coast.

The percentage of females presenting lung alterations was higher than that of males, which may be due to the fact that the number of females is higher than the number of males being born (Marcovaldi et al., 2011).

The macroscopic alterations observed in lungs of C. caretta presenting fungal pneumonia were regions of firm texture, hyperemia and yellowish areas (Schumacher et al., 2014). In this study, the alteration observed in the lung with mycotic inflammation was presence of foam, whereas hyperemia was detected in the cases of heterophilic bronchopneumonia and congestion.

Carrying out research in Lepidochelys kempii, Innis et al. (2009) macroscopically detected the presence of foam, nodules and caseous material distributed in the lung parenchyma; microscopically, the main verified alterations were heterophilic pneumonia associated to bacteria and granulomatous pneumonia related to fungi and parasites. The authors could not establish a relationship between the macro- and microscopic findings. Although the presence of foam is routinely associated to lung edema, this lesion was not observed in the present work.

Here, it was possible to observe inflammatory processes associated to infectious agents. According to Flint et al. (2009), the lungs of free-living turtles can be afflicted by viral, bacterial, fungal and parasitic infections, besides neoplastic processes and obstructions. Nevertheless, bacterial and fungal infections are opportunist, and happen when the animals are immuno-compromised (Rosenthal and Mader, 2006). The fact itself that the animals were found stranded demonstrates that they were not healthy, and the development of lesions may have been a consequence of their displayed weakness.

The most observed lung alteration in this study was heterophilic bronchopneumonia; yet, it was not possible to detect the presence of infectious agents, similarly to the report in $C$. caretta (Stacy et al., 2010). However, bacterial colonization is usually associated to heterophilic inflammations (Gordon et al., 1998). In turtles, the reactions involving heterophils correspond to early responses, as in reptiles these cells constitute the first line of defense; when present, they suggest that the lesion has settled only days before death. Differently, granulomas require more time to form, indicating older lesions (Innis et al., 2009). A study of $C$. mydas infection by Chlamydia sp. did not demonstrate macroscopic lesions, and microscopically, discrete to moderate pneumonia was observed with presence of heterophils, lymphocytes, and macrophages, without formation of granulomas (Homer et al., 1994), which raises the suspicion that, although bacteria 
were not observed via microscopy, it is possible that the animals were infected.

In turn, the reports of infection in E. imbricata refer to colitis associated to infection by Salmonella regent, which was responsible for the death of one specimen (Keymer et al., 1968) and peritonitis caused by Pseudomonas sp., also in one specimen (Glazebrook and Campbell, 1990). In the animals of this study it was possible to observe bacterial colonies inducing granulomatous response. Yet, it was not possible to determine their genus and species, as during necropsy no material was collected for microbiological examination and Ziehl-Neelsen staining was negative.

Parasitic pneumonia caused by spirorchiids constituted the second largest finding during the study $(27.28 \%)$. The occurrence of eggs generating granulomatous response with giant cells was also observed in C. mydas (Gordon et al., 1998). Although collection of spirorchiids was not performed during the necropsies, they have been reported in E. imbricata individuals in Brazil (Werneck et al., 2014).

In C. caretta, Purpureocillium lilacinum and Beauveria bassiana were isolated in samples of lung showing granulomatous pleurisy and heterophilic granulomatous pneumonia (Schumacher et al., 2014). In reptiles in general, the fungi commonly isolated from lesions belong to the genera Paecilomyces, Penicillium, Fusarium, Geotrichium, Mucor and Aspergillus. Differently, systemic fungal diseases caused by agents from the genera Histoplasma, Coccidioides and Cryptococcus are rarely seen in reptiles (Jacobson et al., 2000). Although organisms were observed immersed in granulomatous process, becoming stained by Grocott's technique, it was not possible to diagnose the fungus causing the wound based on lesion morphology alone.

Though not being observed in this study, the most common viral infection affecting the lungs of free-living turtles or turtles kept in captivity is that caused by herpes viruses. In this case, the lungs present mononuclear cells and eosinophilic intranuclear inclusions observed in the epithelial cells (Cox et al., 1980; Flint et al., 2009).

The positive correlation between pneumonia caused by parasite's eggs and nodules in the lungs corroborates the description of Stacy et al. (2010) and Goldberg et al. (2013), who reported nodules in the lung parenchyma of $C$. mydas. In another study, nodules were also observed in the pleura, adventitious coat of the aortic arch, and pericardium (Glazebrook et al., 1981).

A study performed in C. caretta with infection caused by Mycobacterium chelonae allowed observing caseous nodules in the lung parenchyma (Nardini et al., 2014). Although Mycobacterium sp. was not diagnosed by ZiehlNeelsen staining, it is possible that infection by other bacteria also lead to caseous and cyst formation, hence the positive correlation between caseous material and cyst and bacterial pneumonia.

\section{CONCLUSION}

The data collected in the period between 2010 and 2014 revealed that, in lungs of E. imbricata originated from the states of Espírito Santo and Rio de Janeiro, lesions can be observed in animals stranded alive, subjected to treatment, or found dead. The number of affected females was higher than that of males, and all animals were young. The lung lesions observed macroscopically were presence of foam, hyperemia, nodules in the parenchyma, cyst, and caseous material. The verified microscopic lesions were heterophilic bronchopneumonia, parasitic granulomatous pneumonia caused by spirorchiids, bacterial granulomatous pneumonia, fungal granulomatous pneumonia, and congestion. With regards to the association between macro- and microscopic findings, correlation was found between heterophilic bronchopneumonia, presence of foam, cyst, hyperemia, and nodules in the parenchyma; parasitic granulomatous pneumonia, presence of foam and nodules in the parenchyma; bacterial granulomatous pneumonia, cyst, caseous material, and presence of foam; fungal granulomatous pneumonia and foam; and congestion and hyperemia. 


\section{ACKNOWLEDGEMENTS}

We would like to thank CTA - Meio Ambiente (represented by Dr. Bruno Berger) and Projeto TAMAR - ICMBio (represented by Dr. Cecília Baptistotte, Environmental Analyst) for providing the material for this study, and the Coordenação de Aperfeiçoamento de Pessoal de Nível Superior (CAPES) for financial support.

\section{REFERENCES}

COX, W.R.; RAPLEY, W.A.; BARKER, I.K. Herpesvirus-like infection in a painted turtle (Chrysemys picta). J. Wildl. Dis., v.16, p.445449, 1980.

DUTRA, G.H.P.; SILVA, A.N.E.; NASCIMENTO, C.L. et al. Lesões macroscópicas e histopatológicas da infecção por helmintos da família spirorchiidae em Eretmochelys imbricata Linnaeus 1758 (Testudines, Chelonidae): relato de um caso no litoral brasileiro. Nat. Resour., v.2, p.83-89, 2012.

FLINT, M.; PATTERSON-KANE, J.C.; LIMPUS, C.J. et al. Post mortem diagnostic investigation of disease in free-ranging marine turtle populations: a review of common pathologic findings and protocols. J. Vet. Diagn. Investing., v.21, p.733-759, 2009.

GALLO, B.M.G.; MACEDO, S.; GIFFONI, B.B. et al. Sea turtle conservation in Ubatuba, southeastern Brazil, a feeding area with incidental capture in coastal fisheries. Chelonian. Conserv. Biol., v.5, p.93-101, 2006.

GLAZEBROOK, J.S.; CAMPBELL, R.S.F. A survey of the diseases of marine turtles in northern Australia. II. Oceanarium-reared and wild turtles. Dis. Aquat. Org., v.9, p.97-104, 1990.

GLAZEBROOK， J.S.; CAMPBELL， R.S.F.; BLAIR, D. Pathological changes associated with cardiovascular trematodes (Digenea: Spirorchidae) in a green sea turtle Chelonia mydas (L). J. Comp. Pathol., v.91, p.361-368, 1981.
GLAZEBROOK， J.S.; CAMPBELL， R.S.F.; BLAIR, D. Studies on cardiovascular Fluke (Digenea: Spirorchiidae) infections in sea turtles from the great barrier reef, Queensland, Australia. J. Comp. Pathol., v.101, p.231-250, 1989.

GOLDBERG, D.W.; STAHELIN, G.D.; CEGONI, C.T. et al. Case report: lung Spirorchidiasis in a green turtle (Chelonia mydas) in southern Brazil. Mar. Turtle Newsl., n.139, p.14-15, 2013.

GORDON, A.N.; KELLY, W.R.; CRIBB, T.H. Lesions caused by cardiovascular flukes (Digenea: Spirorchidae) in stranded green turtles (Chelonia mydas). Vet. Pathol., v.35, p.21-30, 1998.

HOMER, B.L.; JACOBSON, E.R.; SCHUMACHER, J. et al. Chlamydiosis in mariculture-reared green sea turtles (Chelonia mydas). Vet. Pathol., v.31, p.1-7, 1994.

INNIS, C.; NYAOKE, A.C.; WILLIAMS, C.R. et al. Pathologic and parasitologic findings of cold-stunned kemp's ridley sea turtles (Lepidochelys kempii) stranded on cape cod, Massachusetts, 2001-2006. J. Wildl. Dis., v.45, p.594-610, 2009.

JACOBSON, E.R.; CHEATWOOD, J.L.; MAXWELL, L.K. Mycotic diseases of reptiles. Semin. Avian Exotic Pet Med., v.9, p.94-101, 2000.

KEYMER, I.F.; RIDEALGH, D.; FRETWELL, G. Salmonella regent: a new species associated with colitis in a Pacific hawksbill turtle (Eretmochelys imbricata bissa). J. Pathol. Bacteriol., v.96, p.215-217, 1968.

MARCOVALDI, M.A.; LOPEZ, G.L.; SANTOS, A.J.B. et al. Avaliação do estado de conservação da tartaruga marinha Eretmochelys imbricata (Linnaeus, 1766) no Brasil. Bio Bras., v.1, p.20-27, 2011.

MARCOVALDI, M.A.; MARCOVALDI, G.G. (Eds.). Projeto Tamar: área de desova, ocorrência e distribuição das espécies, época de reprodução, comportamento de postura e técnicas de conservação das tartarugas marinhas no Brasil. Brasília: Ministério da Agricultura /IBDF, 1985. 46p. 
MARCOVALDI, M.A.; MARCOVALDI, G.G. Marine turtles of Brazil: the history and structure of projeto TAMAR-IBAMA. Biol. Conserv., v.91, p.35-41, 1999.

NARDINI, G.; FLORIO, D.; GIROLAMO, N. et al. Disseminated mycobacteriosis in a stranded loggerhead sea turtle (Caretta caretta). J. Zoo Wildl. Med., v.45, p.357-360, 2014.

ROSENTHAL, K.L.; MADER, D.R. Bacterial diseases. In: MADER, D.M. (Ed.). Reptile medicine and surgery. 2.ed. Missouri: Elsevier, 2006. p.227-238.

SANTORO, M.; MORALES, J.A.; BOLAÑOS, F. et al. Helminths of hawksbill turtle (Eretmochelys imbricata) from the Pacific coast of Costa Rica. Helminthology, v.52, p.67-70, 2015.
SCHUMACHER, V.L.; MANGOLD, B.; LENZYCKI, J. et al. Occurrence of fruiting structures allows determination of Purpureocillium lilacinum as an inciting agent of pleuritis and pneumonia in a loggerhead sea turtle (Caretta caretta) by histopathologic correlation to culture. Med. Mycol., v.6, p.42-45, 2014.

STACY, B.A.; FOLEY, A.M.; GREINER, E. et al. Spirorchiidiasis in stranded loggerhead Caretta caretta and green turtles Chelonia mydas in Florida (USA): host pathology and significance. Dis. Aquat. Organ., v.89, p.237$259,2010$.

WERNECK, M.R.; BALDASSIN, P.; D'AZEREDO, F. et al. The hawksbill sea turtle Eretmochelys imbricata Linnaeus 1758 (Testudines, Cheloniidae) as new host of Hapalotrema postorchis Rao, 1976 (Digenea: Spirorchiidae). Comp. Parasitol., v.81, p.75-78, 2014. 